\title{
Bronchiolitis obliterans in a patient with localized scleroderma treated with D-penicillamine
}

\author{
A. Boehler*, P. Vogt**, R. Speich*, W. Weder+, E.W. Russi*
}

Bronchiolitis obliterans in a patient with localized scleroderma treated with D-penicillamine. A. Boehler, P. Vogt, R. Speich, W. Weder. E.W. Russi. (CERS Journals Ltd 1996. ABSTRACT: D-penicillamine-associated bronchiolitis obliterans (BO) is a rare but well-known pulmonary complication in patients with rheumatoid arthritis or progressive systemic sclerosis. It has been assumed that in most, if not all cases, BO is a complication of the underlying disease rather than a side-effect of treatment.

We report the case of a 46 year old man with scleroderma localized to his lower legs (morphea), who received a daily dose of $750 \mathrm{mg}$ D-penicillamine. During the treatment of $1 \mathrm{yr}$ duration, he developed progressive shortness of breath due to a worsening obstructive ventilatory defect suggesting $\mathrm{BO}$, which was confirmed by surgical lung biopsy (constrictive BO). Bronchial obstruction progressed over the next 5 yrs and did not respond to corticosteroids. The patient finally underwent a successful single left lung transplantation. The histological features of constrictive BO were confirmed in the explanted lung.

This observation suggests that D-penicillamine may induce bronchiolitis obliterans in the absence of a systemic connective tissue disease.

Eur Respir J., 1996, 9, 1317-1319.

\begin{abstract}
*Dept of Internal Medicine, Division of Pneumology, **Dept of Pathology and +Dept of Surgery, University Hospital, Zuerich, Switzerland.
\end{abstract}

Correspondence: E.W. Russi, Pulmonary Division, Dept of Internal Medicine, University Hospital, Raemistr. 100, CH-8091 Zurich, Switzerland

Keywords: Bronchiolitis obliterans D-penicillamine

lung transplantation

progressive systemic sclerosis

rheumatoid arthritis

scleroderma

Received: July 311995

Accepted after revision January 271996
D-penicillamine is used to treat rheumatoid arthritis, progressive systemic sclerosis and primary biliary cirrhosis $[1,2]$. Side-effects are numerous and may involve the skin, the gastrointestinal tract, the kidneys or the haemopoetic system. D-penicillamine may also induce neuromuscular alterations or lupus erythematodes. A wide spectrum of pulmonary complications, such as bronchiolitis obliterans (BO), interstitial pneumonitis, alveolar haemorrhage and bronchospasm have been described [1]. However, almost all pulmonary side-effects except pulmonary haemorrhage [3, 4] are found exclusively in patients treated with D-penicillamine for rheumatoid arthritis or progressive systemic sclerosis [1, 5-16]. Furthermore, it is well-known that BO may occur in patients with rheumatoid arthritis who have never received Dpenicillamine [15]. Therefore, most authors suggest that
$\mathrm{BO}$ is a complication of rheumatoid arthritis itself and not a side-effect of treatment with D-penicillamine [16].

\section{Case report}

A 46 year old car mechanic presented in November 1987 with localized skin lesions on both lower legs. His previous medical history was unremarkable. He had stopped smoking 12 yrs previously (10 pack-yrs). The indurated skin lesions were $5 \mathrm{~cm}$ in diameter and showed central ulcerations. Otherwise, physical examination was normal apart from a truncal vitiligo. The following laboratory examinations were within normal limits: complete blood count, serum electrolytes, glucose, creatinine, urinanalysis, liver function tests, immunoglobulins A, G and $\mathrm{M}$ (IgA, $\operatorname{IgG}$ and $\operatorname{IgM})$, serum complement, serum

Table 1. - Pulmonary function tests

\begin{tabular}{|c|c|c|c|c|c|c|c|c|c|c|}
\hline \multicolumn{2}{|l|}{ Date } & \multirow{2}{*}{$\begin{array}{c}8 / 1988 \\
5.1\end{array}$} & \multirow{2}{*}{$\frac{8 / 1989}{3.7}$} & \multirow{2}{*}{$\frac{12 / 1991}{4.5}$} & \multirow{2}{*}{$\frac{6 / 1992}{3.7}$} & \multirow{2}{*}{$\frac{8 / 1993}{3.3}$} & \multirow{2}{*}{$\begin{array}{c}5 / 1994 \\
2.5\end{array}$} & \multirow[t]{2}{*}{ 7/1994 } & \multirow{2}{*}{$\begin{array}{c}10 / 1994 \\
4.5\end{array}$} & \multirow{2}{*}{$\begin{array}{c}4 / 1995 \\
4.2\end{array}$} \\
\hline $\mathrm{VC}$ & $\mathrm{L}$ & & & & & & & & & \\
\hline & $\%$ pred & 108 & 77 & 91 & 77 & 67 & 55 & & 96 & 90 \\
\hline FEV1 & $\mathrm{L}$ & 4.3 & 1.4 & 1.2 & 1.0 & 0.85 & 0.82 & $00 . \bar{\Xi}$ & 2.9 & 2.8 \\
\hline & $\%$ pred & 120 & 39 & 31 & 27 & 23 & 22 & $\Xi$ & 81 & 78 \\
\hline TLC & $\mathrm{L}$ & & & 8.7 & & 10.6 & 10.4 & $\therefore \approx$ & 7.9 & 7.1 \\
\hline & $\%$ pred & & & 120 & & 145 & 142 & $=0$ & 110 & 100 \\
\hline RV & $\mathrm{L}$ & & & 4.2 & & 7.3 & 7.4 & 的 & 3.3 & 2.76 \\
\hline & $\%$ pred & & & 191 & & 324 & 324 & & 148 & 121 \\
\hline$T \mathrm{~L}, \mathrm{CO}$ & $\%$ pred & & & 105 & & 70 & 68 & & & \\
\hline
\end{tabular}

VC: vital capacity; FEV1: forced expiratory volume in one second; TLC: total lung capacity; RV: residual volume; TL,CO: single-breath transfer factor of the lung for carbon monoxide; $\%$ pred: percentage of predicted value. 
rheumatoid factor, anti-nuclear antibodies, anti-smooth muscle cell antibodies, anti-ribonucleoprotein, anti-single strand $\mathrm{A}$ and $\mathrm{B}$, anticentromere and anti-Scl 70. A chest radiograph was normal. The patient did not exhibit Raynaud's phenomena, sicca symptoms, shortness of breath or dysphagia. Localized scleroderma (morphea) was diagnosed.

In August 1988, a treatment consisting of $750 \mathrm{mg} \mathrm{D-}$ penicillamine daily was initiated. Pulmonary function tests were normal (table 1) and the patient used to cycle $20 \mathrm{~km} \cdot$ day $^{-1}$.

During the 12 months of therapy, he developed progressive dyspnoea on exertion, and cough. The symtoms were not preceded by an upper respiratory tract infection. Examination of the lung revealed bilateral inspiratory squeaks. Further physical examination was within normal limits. The skin lesions were unchanged but the central ulcerations had disappeared. All the above-mentioned laboratory findings were repeated and were normal. An electrocardiogram and a lung perfusion scan were unrevealing. The chest radiograph showed marked hyperinflation and a computed tomographic (CT) scan revealed a mosaic pattern. Pulmonary function tests documented severe airflow obstruction (table 1). Open lung biopsy revealed several bronchioles with a broad submucosa consisting of fibroblastic tissue proliferation and infiltrates of lymphocytes, plasma cells and some eosinophils. The lumina of the bronchioles were markedly narrowed but open (fig. 1). The cell infiltrates extended into the peribronchiolar regions but the alveoli were of normal structure. A diagnosis of constrictive BO was made.

D-penicillamine was discontinued. The patient received prednisone (1 mg. $\mathrm{kg}^{-1}$ body weight (BW) daily), which was slowly tapered over the subsequent months to $10 \mathrm{mg}$ daily. Despite treatment, the airflow obstruction progressed over the following 5 yrs and was unresponsive to bronchodilatators. Pulmonary hyperinflation worsened but lung diffusing capacity remained within normal limits (table 1).

The patient was finally unable to leave his house and was listed for lung transplantation in May 1994. At this time, a re-evaluation with regard to progression from localized scleroderma to systemic sclerosis, particularly capillary microscopy, revealed negative results. Systolic pulmonary artery pressure was $24 \mathrm{mmHg}$. Left ventricular function and coronary angiography were normal.

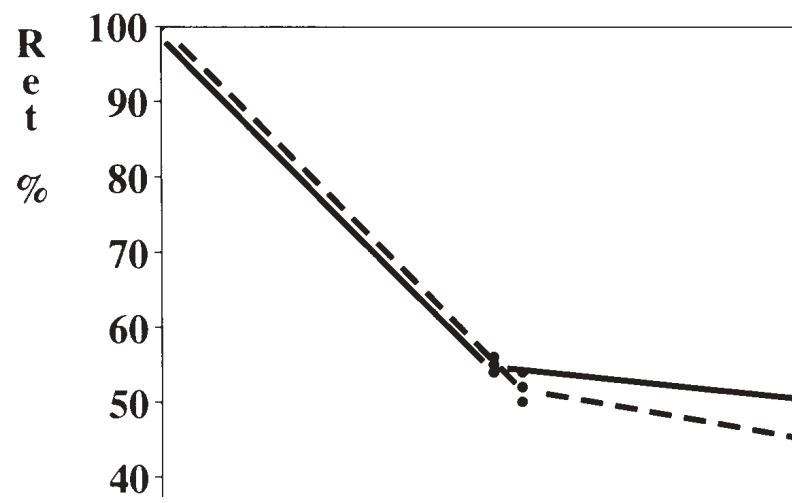

Fig. 1. - Open lung biopsy: bronchiolus with marked narrowing of the lumen due to proliferated fibrous tissue (arrow head) and inflammatory cell infiltrates in the submucosa (HE stain, original magnification $\times 160$ ).

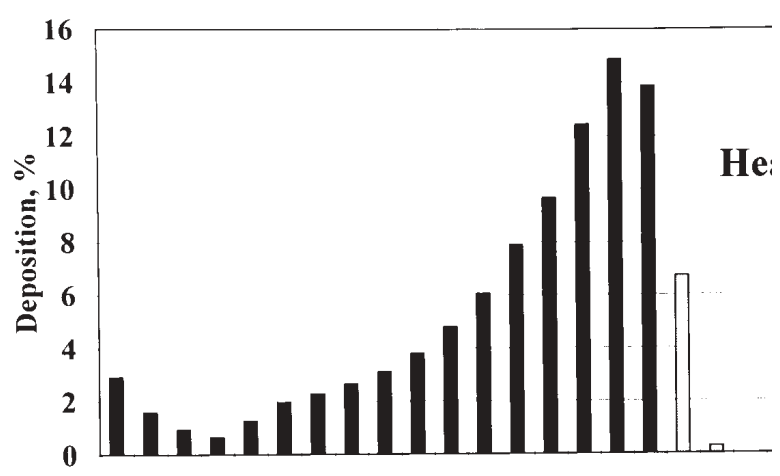

Fig. 2. - Explanted lung showing bronchiolus completely obliterated by scar tissue. (Haematoxylin and eosin stain, original magnification $\times 100$ ).

A left single lung transplantation was performed in July 1994. In the explanted lung, some normal bronchioles and numerous bronchioles devoid of epithelia and completely obstructed by connective tussue were visible (fig. 2).

The postoperative course was uneventful and, after rehabilitation, the patient resumed work. Forced expiratory volume in one second (FEV1) increased from 0.82 to $2.9 \mathrm{~L}$ (table 1). Repeated surveillance transbronchial biopsies have shown no signs of recurrence of the underlying disease (BO) up to now. Also, the patient's skin lesions have not changed.

\section{Discussion}

To our knowledge, this is the first case of constrictive BO in a patient treated with D-penicillamine for localized scleroderma without evidence of progressive systemic sclerosis or rheumatoid arthritis.

Histopathologically, BO can be divided into two different subgroups: constrictive bronchiolitis with concentric narrowing of the bronchioles; and proliferative bronchiolitis with fibrous tissue proliferation in the small airways $[17,18]$. Constrictive BO is observed after bone-marrow [19], heart-lung and lung transplantation [20], after viral infections or infections with mycoplasma [21], after inhalation of toxic fumes [21], and in association with ulcerative colitis [22]. These aetiologies were excluded in our patient. Constrictive BO is also described in association with collagen vascular diseases [23]. In systemic lupus erythematosis, BO is very rare and only a few cases have been reported, mostly not biopsy proven [23]. Sjögren's syndrome is known to be associated with different types of BO (follicular and lymphocytic bronchiolitis) [23]. BO has not been observed in patients with polymyositis and dermatomyositis.

$\mathrm{BO}$ has been observed in patients with rheumatoid arthritis, mainly affecting middle-aged women, with severe disease lasting over many years [1, 7, 13, 15, 16, 24]. Recently, a case of constrictive $\mathrm{BO}$ as first manifestation of rheumatoid arthritis was reported [25]. About $50 \%$ of patients with rheumatoid arthritis who developed BO have been treated with D-penicillamine. Since the symptoms of $\mathrm{BO}$ have occurred on average 7.8 months after D-penicillamine has been started, BO could be a sideeffect of the treatment itself [13]. However, it has been postulated that patients with rheumatoid arthritis may be 
particularly prone to the development of $\mathrm{BO}$ during treatment with D-penicillamine, since patients receiving this drug for other indications, such as Wilson's disease, biliary cirrhosis or fibrosing alveolitis, have not been observed to develop BO (5).

Patients with systemic sclerosis are well-known to develop restrictive ventilatory defects and impaired gas transfer, due to fibrosing alveolitis [26, 27] and a preferential involvement of small lung vessels [28]. Few cases of systemic sclerosis have been reported with biopsy proven BO $[5,16]$. In one case, the symptoms of BO started before [16], and in another during treatment with D-penicillamine [5].

Our patient developed severe BO during $1 \mathrm{yr}$ of treatment with D-penicillamine. He was suffering from circumscript scleroderma localized on his lower extremities and had no clinical or serological evidence for progressive systemic sclerosis or other systemic connective tissue disease. This case suggests that BO may occur as a side-effect of D-penicillamine, since our patient did not suffer from rheumatoid arthritis or other disease known to be associated with $\mathrm{BO}$.

As known from patients with rheumatoid arthritis, the clinical course of our patient with D-penicillamine-associated bronchiolitis obliterans was progressive, although the drug was discontinued. Lung transplantation in endstage disease is a new therapeutic modality and was successfully performed in our patient.

\section{References}

1. Camus $\mathrm{Ph}$. Manifestations respiratoires associées aux traitements par la D-pénicillamine. Rev Fr Mal Respir 1982; 10: 7-20.

2. Lyle WH. D-penicillamine and fatal obliterative bronchiolitis. BMJ 1977; 1: 105.

3. Stemlieb P, Bennett B, Scheinberg IH. D-penicillamine induced Goodpasture's syndrome in Wilson's disease. Ann Intern Med 1975; 82: 673-676.

4. Matloff DS, Kaplan MM. D-penicillamine-induced Goodpasture's like syndrome in primary biliary cirrhosis: successful treatment with plasmapheresis and immunosuppressives. Gastroenterology 1980; 78: 1046-1049.

5. Epler GR, Snider GL, Gaensler EA, Cathcart ES, FitzGerald MX, Carrington CB. Bronchiolitis and bronchitis in connective tissue disease. JAMA 1979; 242: 528-532.

6. Geddes DM, Corrin B, Brewerton DA, Davies RJ, TurnerWarwick M. Progressive airway obliteration in adults and its association with rheumatoid disease. $Q \mathrm{~J} \mathrm{Med}$ 1977; 46: 427-444.

7. Cordier JF, Moulin J, Brune J, Moulin G, Touraine R. Accidents respiratoires au cours de traitements par la Dpénicillamine: alvéolites et bronchiolites. Rev Fr Mal Respir 1981; 9: 319-326.

8. Murphy KC, Atkins CJ, Offer RC, Hogg JC, Stein HB. Obliterative bronchiolitis in two rheumatoid arthritis patients treated with penicillamine. Arthritis Rheum 1981; 24: 557-560.

9. Geraads A, Brambilla E, Hohn B, Piton JL, Blanc-Jouvan F, Kamel A. Polyarthrite rhumatoide, bronchiolite oblitérante et D-penicillamine. Poumon Coeur 1983; 39: 257-262.
10. Van de Laar MA, Westermann CJ, Wagenaar SS, Dinant HJ. Beneficial effect of intravenous cyclophosphamide and oral prednisone on D-penicillamine-associated bronchiolitis obliterans. Arthritis Rheum 1985; 28: 93-97.

11. Renier JC, Bontoux-Carre E, Racineux JL. Trois observations de bronchiolite oblitérante lors du traitement de la polyarthrite rhumatoide par la D-pénicillamine. Rev Rhum 1986; 53: 25-26.

12. Penny WJ, Knight RK, Rees AM, Thomas AL, Smith AP. Obliterative bronchiolitis in rheumatoid arthritis. Ann Rheum Dis 1982; 41: 469-472.

13. Wolfe F, Schurle DR, Lin JJ, et al. Upper and lower airway disease in penicillamine-treated patients with rheumatoid arthritis. J Rheumatol 1983; 10: 406-410.

14. Eastmond CJ. Diffuse alveolitis as complication of penicillamine treatment for rheumatoid arthritis. BMJ 1976; 1: 1506.

15. Herzog CA, Miller RR, Hoidal JR. Bronchiolitis and rheumatoid arthritis. Am Rev Respir Dis 1981; 124: 636-639.

16. Hakala M, Pääkkö P, Sutinen S, Hukti E, Koivisto O, Tarkka M. Association of bronchiolitis with connective tissue disorders. Ann Rheum Dis 1986; 45: 656662.

17. Myers JL, Colby TV. Pathologic manifestations of bronchiolitis, constrictive bronchiolitis, cryptogenic organizing pneumonia and diffuse panbronchiolitis. Clin Chest Med 1993; 14(4): 611-622.

18. King TE Jr. Overview of bronchiolitis. Clin Chest Med 1993; 14(4): 607-610.

19. Clark J, Crawford S, Madtes D. Obstructive lung disease after allogeneic marrow transplantation: clinical presentation and course. Ann Intern Med 1989; 111: 368-376.

20. Burke CM, Theodore J, Dawkins KD. Post-transplant obliterative bronchiolitis and other late lung sequelae in human heart-lung transplantation. Chest 1984; 86: 824829.

21. King TE Jr. Bronchiolitis obliterans. Lung 1989; 167: 69-93.

22. Wilcox P, Miller R, Miller G. Airway involvement in ulcerative colitis. Chest 1987; 92: 18-22.

23. Wells AU, du Bois RM. Bronchiolitis in association with connective tissue disorders. Clin Chest Med 1993; 14(4): 655-666.

24. Sweatman MC, Markwick JR, Charles PJ, et al. Histocompatibility antigens in adult obliterative bronchiolitis with or without rheumatoid arthritis. Dis Markers 1986; 4: 19-26.

25. Schwarz MI, Lynch DA, Tuder R. Bronchiolitis obliterans: the lone manifestation of rheumatoid arthritis? Eur Respir J 1994; 7: 817-820.

26. König G, Luderschmidt C, Hammer C, Adelmann-Grill B, Braun-Falco O, Fruhmann G. Lung involvement in scleroderma. Chest 1984; 85: 318-324.

27. Harrison NK, Glanville AR, Strickland B, et al. Pulmonary involvement in systemic sclerosis: the detection of early changes by thin section $\mathrm{CT}$ scan, bronchoalveolar lavage and 99mTc-DTPA clearance. Respir Med 1989; 83: 403414.

28. Manoussakis MN, Constantopoulos SH, Gharavi AE, Moutsopoulos HM. Pulmonary involvement in systemic sclerosis: association with anti-Scl 70 antibody and digital pitting. Chest 1987; 92: 509-513. 